\title{
Geographical and anatomical influences on human papillomavirus prevalence diversity in head and neck squamous cell carcinoma in Germany
}

\author{
ELGAR SUSANNE QUABIUS ${ }^{1,2}$, JOCHEN HAAG $^{3}$, ANDRÉ KÜHNEL ${ }^{1}$, HANNES HENRY $^{1}$, \\ ANNA SOPHIE HOFFMANN ${ }^{4}$, TIBOR GÖRÖGH ${ }^{1}$, JÜRGEN HEDDERICH ${ }^{5}$, \\ MATTHIAS EVERT ${ }^{6}$, ACHIM G. BEULE $^{7}$, STEFFEN MAUNE $^{8}$, RAINALD KNECHT ${ }^{9}$, \\ ATTILA ÓVÁRI ${ }^{10}$, MARTIN DURISIN $^{11}$, FLORIAN HOPPE $^{12}$, SILKE TRIBIUS $^{13}$, \\ CHRISTOPH RÖCKEN ${ }^{3}$, PETRA AMBROSCH$^{1}$ and MARKUS HOFFMANN ${ }^{1}$
}

\footnotetext{
${ }^{1}$ Department of Otorhinolaryngology, Head and Neck Surgery, Christian-Albrechts-University Kiel; ${ }^{2}$ Institute of Immunology Christian-Albrechts-University Kiel; ${ }^{3}$ Institute for Pathology, Christian-Albrechts-University Kiel, D-24105 Kiel; ${ }^{4}$ Department of Otorhinolaryngology, University of Schleswig-Holstein, Campus Lübeck, D-23538 Lübeck; ${ }^{5}$ Institute for Medical Informatics and Statistics, Christian-Albrechts-University Kiel, D-24105 Kiel; ${ }^{6}$ Institute for Pathology, Ernst-Moritz-Arndt-University of Greifswald, D-17487 Greifswald; ${ }^{7}$ Department of Otorhinolaryngology, Head and Neck Surgery, Ernst-Moritz-Arndt-University of Greifswald, D-17475 Greifswald; ${ }^{8}$ Department of Otorhinolaryngology, Hospitals of the City of Cologne, Cologne, D-51067 Köln; ${ }^{9}$ Department of Oto-RhinoLaryngology, Head and Neck Surgery, University Medical Centre Hamburg-Eppendorf, D-20246 Hamburg;

${ }^{10}$ Department of Otorhinolaryngology, Head and Neck Surgery, University of Rostock, D-18057 Rostock; ${ }^{11}$ Department of Otorhinolaryngology, Medical University of Hannover, D-30625 Hannover; ${ }^{12}$ Department of Otorhinolaryngology-Head and Neck Surgery, Klinikum Oldenburg, D-26133 Oldenburg; ${ }^{13}$ Department of Radiation Oncology, University Medical Center Hamburg-Eppendorf, D-20246 Hamburg, Germany
}

Received July 4, 2014; Accepted August 21, 2014

DOI: 10.3892/ijo.2014.2697

\begin{abstract}
The increased knowledge regarding HPV-infections in head and neck squamous cell carcinoma (HNSCC) has unexpectedly contributed to several uncertainties related to i) prevalence diversities depending on tumour site and geographical origin of the patients, ii) proportion of HPV-driven tumours among HPV-DNA-positive cases, and iii) identification of patients with HPV-attributed survival benefit. To investigate this heterogeneity, we analysed 307 HNSCC cases (tonsillar, $\mathrm{n}=135$; non-tonsillar, $\mathrm{n}=172$ ) from eight health care centers mostly from Northern Germany and determined HPV-DNA/mRNA and p16 $6^{\mathrm{INK} 4 \mathrm{~A}}$-status and combined results with the patient outcome. Overall HPV-DNA prevalence rate was $23.5 \%$ (72/307); attributed to: $43.7 \%$ (59/135) and
\end{abstract}

Correspondence to: Dr Markus Hoffmann, Department of Otorhinolaryngology, Head and Neck Surgery, Christian-AlbrechtsUniversity Kiel, Arnold-Heller-Strasse 3, Building 27, D-24105 Kiel, Germany

E-mail:mhoffmann@hno.uni-kiel.de

Key words: human papillomavirus, p16INK4A, E6mRNA,E7mRNA, head and neck squamous cell carcinoma, geography
$7.6 \%(13 / 172)$ tonsillar and non-tonsillar cases, respectively. Among these, $96.6 \%$ tonsillar and $38.5 \%$ non-tonsillar SCC were HPV-mRNA-positive. Although the study cohort was composed of patients from regions of rather close proximity, prevalence rates showed diversities of up to $40 \%$ in HNSCC subsite analysis with the lowest prevalence for tonsillar SCC in metropolitan areas (22.2\%) vs. 50.9\% in rural areas. Survival analysis identified $\mathrm{p} 16^{\mathrm{INK4A}}$ alone as strongest predictor, followed by HPV-DNA-status alone or in combination with p16 ${ }^{\text {INK4A }}$. This survival benefit was shown for tonsillar and non-tonsillar cases. Smoking significantly correlated with HPV-status, however, it does not influence survival when stratified for HPV. In conclusion, the data emphasize the urge for further data on HPV-infection in HNSCC to, e.g. clarify to what extent survival benefits of $\mathrm{p} 16^{\mathrm{INK} 4 \mathrm{~A}}$-positive patients are truly attributed to HPV-infections.

\section{Introduction}

Human papillomavirus (HPV) infection is an important feature causing a specific subset of head and neck squamous cell carcinoma (HNSCC). Specifically SCC of the palatine and lingual tonsils, located in the anatomical region of the oropharynx, are connected to infections with predominantly HPV genotype 16 (1-4). HPV positive HNSCC are considered a tumour entity with patients being younger, male, Caucasians, 
and showing overall and recurrence-free survival rates superior to those of HPV negative patients $(1,5,6)$. The latter most likely is true for cases with active HPV infections, characterized by mRNA expression of the viral E6/E7 proteins as direct marker or, in consequence of a negative feedback regulation to $\mathrm{E} 7$ activity, p16 ${ }^{\mathrm{INK} 4 \mathrm{~A}}$ overexpression as indirect marker (7-12). HNSCC harbouring active HPV infections are considered to be truly HPV-driven (7). The impressive survival advantage of cases positive for active HPV infections have been demonstrated in diverse populations worldwide $(1,2,5,13)$. This prompted clinicians to consider modifications of established treatment regimens, specifically radiotherapy regimes since survival advantages have repeatedly been attributed to higher radiosensitivity of HPV positive cases. De-intensification of radiotherapy applied to patients with HPV-driven HNSCC consecutively minimizing treatment morbidity is momentarily discussed as the HPV-dependent treatment option (14).

It is important to keep in mind that the majority of HPV positive patients receive (adjuvant) radio(chemo)therapy for the following reason: at first time presentation, patients with HPV-positive HNSCC regularly show higher disease burden, specifically higher lymph nodal masses in the lateral neck $(15,16)$, assigning these patients for treatment strategies including radiotherapy. Thus, unaware of the HPV status the majority of patients with actually HPV-driven tumours receive the most promising treatment regime exclusively based on their clinical tumour characteristics.

There is an increasing amount of studies reporting on diverging HPV prevalence rates (0-90\%) throughout the world (3-5,13,17-19). Discordant recommendations how to identify true HPV-driven cancers and, thereby cases with the best prognosis, namely by either i) viral mRNA detection or by ii) p16 ${ }^{\mathrm{INK} 4 \mathrm{~A}}$ immunohistochemistry performed additionally to HPV DNA detection, by iii) a combination of both or even other parameters or iv) determination of HPV related methylation signatures, and v) in situ hybridization techniques $(5,7-9,11,13,20-23)$ do hamper the routine diagnosis of HPV status in HNSCC patients and cause uncertainties among clinicians. Additionally, there is increasing data describing a subgroup of patients showing p16 ${ }^{\text {INK4A }}$ overexpression, yet, either being completely HPV negative or HPV DNA-positive but HPV mRNA-negative, thus, not bearing HPV-driven tumours $(9,24)$.

In the present study, we determined the HPV infection status of HNSCC from 307 patients with tonsillar and nontonsillar tumours collected from eight health care centres mostly from Northern Germany and investigated HPV DNA-, E6/E7 mRNA presence and p16 ${ }^{\mathrm{INK} 4 \mathrm{~A}}$ expression in the tumour specimens in a single laboratory setting. The aim of the study was to i) determine the prevalence rate of active HPV infections comparing tonsillar and non-tonsillar tumours, ii) investigate possible geographical influences on prevalence rates, iii) identify parameters or combinations of parameters of highest prognostic value, and iv) specifically focus on the subgroup of patients with HPV-independent $\mathrm{p} 16^{\mathrm{INK} 4 \mathrm{~A}}$ overexpression.

\section{Materials and methods}

Patients, tissue specimens, DNA and RNA extraction. FFPE tissue samples of histopathologically confirmed HNSCC were obtained during surgery between 2001 and

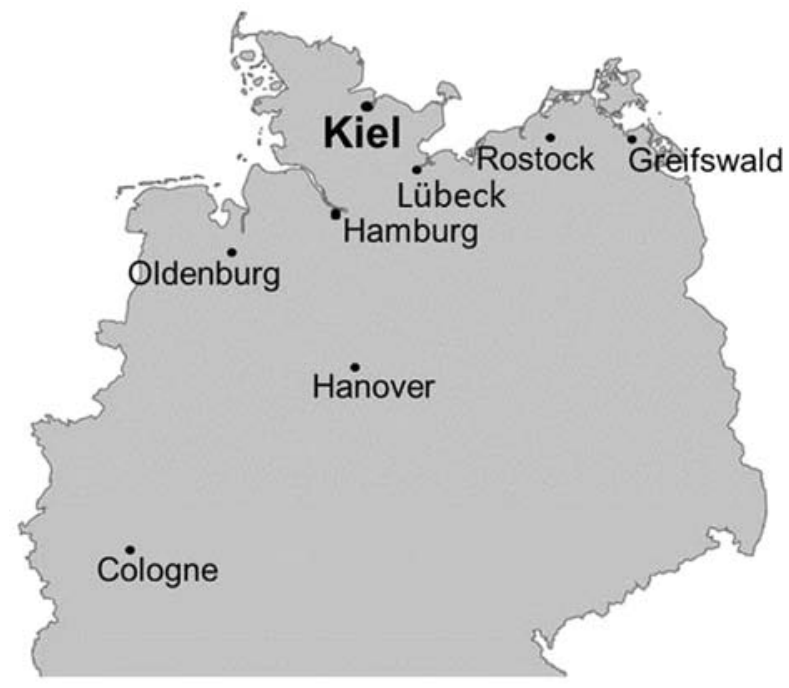

Figure 1. Map of North-Western Germany indicating participating cancer clinics. Kiel, capital of the County of Schleswig-Holstein, is indicated in bold, to highlight the clinic where all the analysis were performed. Number of inhabitants, city area and average age of inhabitants are as follows: Kiel: 237,694; $118.6 \mathrm{~km}^{2} ; 41.9$ years; Lübeck: 213,865; $214.1 \mathrm{~km}^{2} ; 44.3$ years; Rostock: 200,$465 ; 181.4 \mathrm{~km}^{2} ; 43.9$ years; Greifswald: 60,$822 ; 50.5 \mathrm{~km}^{2}$; 41.8 years; Hamburg: 1,734,272; 755.3 km²; 44.4 years; Oldenburg: 157,706; $102.9 \mathrm{~km}^{2}$; 42.3 years; Hanover: 525,875; 204,1 km²; 42.7 years; Cologne: $1,013,665 ; 405.2 \mathrm{~km}^{2} ; 41.7$ years. All cities are university cities; Hanover is the Capital of the County of Lower Saxony and Hamburg the capital of the County of Hamburg.

2009 from 311 patients (229 male; 82 female; 28-91 years, mean: $61.6 \pm 10.9$ years) receiving treatment at the various German HNSCC cancer centres participating in this study. The samples were sent to the Institute of Pathology, ChristianAlbrechts-University Kiel, Germany, and stored for further analysis.

Participating centres were located in Rostock, Greifswald, Kiel, Lübeck, Hanover, Oldenburg, Hamburg, and Cologne (see Fig. 1). All patients were Caucasians and had no migration background. For further analysis with the aim to increase case numbers cases from i) Rostock and Greifswald and ii) Kiel and Lübeck were investigated as one group, respectively (each grouping was based on comparability of city characteristics in terms of infrastructure, population and geographic location rather than geographical distance). Details of participating centres can be found in the list of affiliations. Number of cases contributed and first results regarding HPV-status and tumour localisation are listed in Table I.

The anatomical location of all analysed primary tumours was as follows: tonsils [ $(\mathrm{n}=135)$ palatine tonsil $(\mathrm{n}=87)$; lingual tonsil $(n=48)]$, larynx $(n=55)$, hypopharynx $(n=38)$, oral cavity $(n=59)$, and oropharynx [other than tonsil $(n=20)$ ]. It is important to note that the centres were asked to contribute similar numbers of tonsillar and non-tonsillar cases. Therefore, case numbers do not reflect distribution of tumour entities of the various centres. In the following tonsillar cases $(n=135)$ and non-tonsillar cases $(n=172)$ were summarized for further molecular and statistical analysis.

Nucleic acid extraction, HPV detection, cDNA synthesis and $q P C R$. DNA was extracted using depending on tumour size tissue 4-6 consecutive $10-\mu \mathrm{m}$ sections derived from 
Table I. Distribution of HPV DNA-positive cases and number of cases investigated from the eight participating cancer centres.

\begin{tabular}{lccccccc}
\hline Centres & Larynx & Hypopharynx & Oropharynx & Oral cavity & Non-tonsil $^{\mathrm{c}}$ & Tonsil $^{\mathrm{d}}$ & Overall $(\%)^{\circ}$ \\
\hline Rostock $^{\mathrm{a}}$ & $-/-$ & $-/-$ & $0 / 3$ & $-/-$ & $0 / 3(0)$ & $11 / 14(78.6)$ & $11 / 17(64.7)$ \\
Greifswald $^{\mathrm{a}}$ & $0 / 1$ & $1 / 3$ & $1 / 4$ & $0 / 4$ & $2 / 12(16.6)$ & $9 / 22(40.9)$ & $11 / 34(32.0)$ \\
Kiel $^{\mathrm{b}}$ & $0 / 6$ & $0 / 10$ & $0 / 1$ & $0 / 3$ & $0 / 20(0)$ & $8 / 18(44.4)$ & $8 / 38(21.1)$ \\
Lübeck $^{\mathrm{b}}$ & $2 / 9$ & $1 / 5$ & $1 / 2$ & $0 / 4$ & $4 / 20(20)$ & $2 / 6(33.3)$ & $6 / 26(23.1)$ \\
Oldenburg & $0 / 9$ & $0 / 5$ & $0 / 2$ & $0 / 13$ & $0 / 29(0)$ & $12 / 26(46.1)$ & $12 / 55(21.8)$ \\
Hanover & $-/-$ & $-/-$ & $-/-$ & $1 / 20$ & $1 / 20(5)$ & $11 / 22(50)$ & $12 / 42(28.6)$ \\
Hamburg & $0 / 13$ & $0 / 10$ & $1 / 5$ & $1 / 4$ & $2 / 32(6.3)$ & $5 / 18(27.8)$ & $7 / 50(14)$ \\
Cologne & $3 / 17$ & $0 / 5$ & $0 / 3$ & $1 / 11$ & $4 / 36(11.1)$ & $1 / 9(11.1)$ & $5 / 45(11.1)$ \\
Overall & $5 / 55(9.1)$ & $2 / 38(5.2)$ & $3 / 20(15)$ & $3 / 59(5.1)$ & $13 / 172(7.6)$ & $59 / 135(43.7)$ & $72 / 307(23.4)$
\end{tabular}

HPV DNA-positive cases/number of cases investigated with percentage in parenthesis; to increase number of cases per location, for further analysis, cases from Rostock/Greifswald ${ }^{\mathrm{a}}$ and Kiel/Lübeck ${ }^{\mathrm{b}}$ were analysed in one group due to comparability of city characteristics in terms of infrastructure, population and geographic location. ${ }^{\mathrm{C} S u m m a r y}$ of all non-tonsillar SCC (including SCC of larynx, hypopharynx, oropharynx and oral cavity); ${ }^{\mathrm{d}}$ Summary of all tonsillar SCC (including SCC of palatine and lingual tonsil).

formalin-fixed paraffin-embedded (FFPE) tissue specimens. DNA extraction and HPV detection was performed, as previously described $(9,25)$.

For RNA extraction 5 consecutive $10 \mu \mathrm{m}$ sections from the above tissue specimens were used. RNA was isolated using the FFPE RNAready kit (AmpTec, Hamburg, Germany) according to the manufacturer's protocol. cDNA synthesis and. qPCR was performed as previously described (26). E6/E7 primers are described elsewhere (27).

Immunohistochemistry for p16 ${ }^{I N K 4 A}$. FFPE tissue specimens (2- $\mu \mathrm{m}$ sections) were stained for $\mathrm{p} 16^{\mathrm{INK} 4 \mathrm{~A}}$ expression as previously described (8). Immunostaining was evaluated according to Klaes and coworkers (28). Depending on these criteria (28) the results were classified as negative $(-)$, weak $(+)$, moderate $(++)$, and strong $(+++)$, respectively.

Statistical analyses. From four of the initially recruited 311 FFPE samples, no DNA could be isolated. These blocks and respective patient information were dismissed from further analysis. Statistical analysis was performed for 280/307 patients; 27 patients were lost to follow-up $(n=17)$ or patient files were incomplete $(n=10)$. Median follow-up was 2.3 years (range, 2.1 to 12.14 years). For survival analysis according to KaplanMeier, primary statistical endpoints were progression-free survival (PFS) and overall survival (OS). PFS and OS were defined as time from first diagnosis to date of disease progression and last follow-up examination or death, respectively. Factors tested for prognostic value included, smoking habit, tumour size ( $\mathrm{T}$, according to the TNM Classification of the UICC 1992), incidence and extent of lymph node metastasis (N, according to the TNM Classification of the UICC 1992), location of the primary tumour, HPV DNA and mRNA status, and $\mathrm{p} 16^{\mathrm{INK} 4 \mathrm{~A}}$ expression in the tissue samples. Log-rank test was used to test for significant differences between the groups. Fisher's exact test was used relating HPV positivity to p16 ${ }^{\text {INK4A }}$ and E6/E7 mRNA expression. p-values $\leq 0.05$ were accepted as statistically significant.

\section{Results}

HPV DNA analysis. HPV DNA analysis was performed in 307 tumour specimens derived from tonsillar $(n=135)$ and nontonsillar $(\mathrm{n}=172)$ SCC patients.

Out of these 307 investigated patients, 72 (23.5\%) showed HPV DNA with an HPV prevalence rate of $43.7 \%$ (59/135) and $7.6 \%$ (13/172) in tonsillar and non-tonsillar cases, respectively. In non-tonsillar SCC, HPV DNA could be detected in SCC of the larynx, $5 / 55$ (9.1\%); the hypopharynx, 2/38 (5.2\%); the oropharynx other than tonsil, 3/20 (15\%); and the oral cavity, $3 / 59(5.1 \%)$. The HPV genotypes detected were HPV16, HPV18, HPV26 and HPV31 in 68, two, and one case each, respectively (Table II). Except for HPV26, which was identified in a tonsillar SCC, all other non-HPV16-types were found in laryngeal SCC.

At first time diagnosis patients with HPV DNA-positive and HPV DNA-negative tumours showed no differences in age ( $>0.05$ ); the same was true for HPV RNA. Moreover, the distribution of cases with T1/T2 and T3/T4 primary tumours was equall among HPV positive and negative patients whereas HPV-positive cases showed significantly higher lymph nodedisease status compared to HPV-negative patients $(\mathrm{p}=0.015$; data not shown). Among HPV DNA positive cases, the number of smokers and non-smokers were approximately the same, whereas among HPV DNA-negative cases there were significantly more smokers than non-smokers $(\mathrm{p}<0.001$, data not shown).

Table I summarizes HPV-positive cases with respect to the anatomical tumour site and the various participating health care centres. Of note, with 12/95 (12.6\%) HPV-positive SCC overall and 6/27 (22.2\%) HPV-positive tonsillar SCC patients treated in health care centres with populations from metropolitan areas (Hamburg, Cologne; population $>1$ million) showed lower HPV prevalence rates than determined in patients treated in the other health care centres with study populations from rather rural areas (Greifswald, Rostock, Lübeck, Kiel, Oldenburg, Hanover; population <550.000). In the latter, HPV 
Table II. Distribution of $16^{\mathrm{INK} 4 \mathrm{~A}}$ staining pattern among the HPV-positive $(\mathrm{n}=72)$ and HPV-negative cases $(\mathrm{n}=235)$ discriminated by the various HPV genotypes identified in this population.

\begin{tabular}{|c|c|c|c|c|c|c|c|}
\hline & HPV16 & HPV 18 & HPV26 & HPV31 & HPV pos. & HPV neg. & Overall \\
\hline $\mathrm{p} 16^{\mathrm{INK} 4 \mathrm{~A}}-$ & $1(\mathrm{RNA}+)$ & - & - & - & $1(\mathrm{RNA}+)$ & 50 & $51(16.6)$ \\
\hline $\mathrm{p} 16^{\mathrm{INK} 4 \mathrm{~A}}+$ & 1 (RNA -) & - & - & 1 (RNA -) & 2 (2 RNA-) & 49 & $51(16.6)$ \\
\hline $\mathrm{p} 16^{\mathrm{INK} 4 \mathrm{~A}}++$ & 3 (2 RNA -) & - & - & - & 3 (2 RNA-) & 104 & $107(34.9)$ \\
\hline $\mathrm{p} 16^{\mathrm{INK4A}}+++$ & 63 (4 RNA -) & 2 (2 RNA -) & $1(\mathrm{RNA}+)$ & - & 66 (6 RNA-) & 32 & $98(31.9)$ \\
\hline Overall & 68 & 2 & 1 & 1 & 72 & 235 & 307 \\
\hline
\end{tabular}

Among HPV-positive cases, strong p16 ${ }^{\mathrm{INK} 4 \mathrm{~A}}$ staining (+++) clearly marks cases with active HPV infections. However, 6/66 (9.1\%) cases in this group were negative for viral mRNA. Out of 6 cases without $\mathrm{p} 16^{\mathrm{INK} 4 \mathrm{~A}}$ expression or with weak to moderate p16 $6^{\mathrm{INK} 4 \mathrm{~A}}$ staining, 2 cases contained active HPV infections. There is a statistical significant correlation between HPV DNA mRNA, respectively, and p16 ${ }^{\mathrm{INK} 4 \mathrm{~A}}$ (p $\leq 0.001$ for both correlations). However, relying on the standard algorithm which assumes that strong $\mathrm{p} 16^{\mathrm{INK} 4 \mathrm{~A}}$ staining (+++) depicts active and missing to moderate $(-,+,++)$ p16 ${ }^{\mathrm{INK} 4 \mathrm{~A}}$ marks inactive HPV infections would have led to the following misclassification: the 6 cases with strong p16 ${ }^{\mathrm{INK} 4 \mathrm{~A}}$ staining, but no viral mRNA would have been treated as HPV-positive cases and the 2 cases with viral mRNA but no (-) and moderate (++) p $16^{\mathrm{INK} 4 \mathrm{~A}}$ staining would have been classified as HPV negative cases.
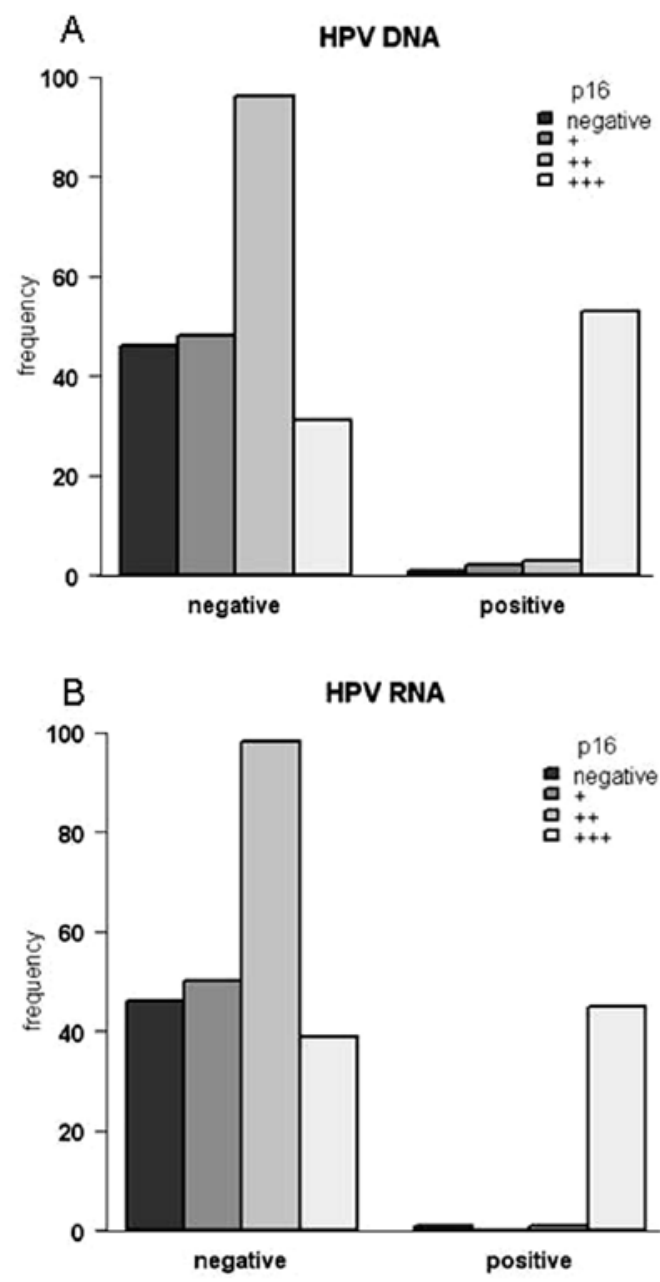

Figure 2. Distribution of $16^{\text {INK4A }}$ staining intensities for HPV DNA-positive and -negative cases (A) and HPV RNA-positive and -negative cases (B). The data clearly advocate to only consider $\mathrm{p} 16^{\mathrm{INK} 4 \mathrm{~A}}+++$ cases as positive in terms of depicting HPV infected cases.

prevalence rates were $28.3 \%(60 / 212)$ and $50.9 \%(55 / 108)$ for overall SCC cases and tonsillar SCC, respectively. This correlation was statistical significant for overall $(\mathrm{p}=0.019)$ and tonsillar $(\mathrm{p}<0.001)$ cases.

Expression of E6/E7 mRNA. HPV DNA-positive cases ( $\mathrm{n}=72)$ and HPV DNA-negative cases with strong p16 ${ }^{\mathrm{INK} 4 \mathrm{~A}}$ staining $(n=32)$ were subjected to HPV E6/E7 mRNA analysis. Amplifiable RNA could be obtained from all cases investigated. All cases with strong p16 ${ }^{\mathrm{INK} 4 \mathrm{~A}}$ staining lacking HPV DNA signals were E6/E7-negative. From the HPV DNA-positive cases $62(86.1 \%)$ were also HPV mRNA-positive and ten cases were HPV DNA-positive without E6/E7 mRNA signals. The latter cases must be assumed as being not HPV-driven. From these ten cases, four could be assigned to patients treated in Lübeck, two in Cologne, one in Hanover, Oldenburg, and Greifswald, respectively. Regarding the anatomical site of the primary tumour 57/59 (96.6\%) HPV DNA-positive tonsillar SCC were HPV mRNA-positive and 5/13 (38.5\%) of HPV DNA positive non-tonsillar SCC cases (oral cavity, $\mathrm{n}=3$; oropharynx other than tonsils, $n=1$; hypopharynx, $n=1$ ), were HPV mRNApositive thus, classifying these cases as HPV-driven.

p16 ${ }^{I N K 4 A}$ expression and correlation to HPV DNA and E6/E7 mRNA expression. Immunohistochemistry revealed 51 out of $307(16.6 \%)$ tissue samples without p16 $6^{\mathrm{INK} 4 \mathrm{~A}}$ expression. According to the criteria by Klaes and colleagues (28), weak, moderate and strong $\mathrm{p} 16^{\mathrm{INK} 4 \mathrm{~A}}$ expression was detected in 51 (16.6\%), $107(34.9 \%)$ and $98(31.9 \%)$ of the p16 $6^{\mathrm{INK} 4 \mathrm{~A}}$-positive cases, respectively (Tables II and III).

Of those cases with strong p16 $16^{\mathrm{INK} 4 \mathrm{~A}}$ staining (+++) $67.3 \%$ (66/98) could be assigned to HPV DNA-positive tumours $(\mathrm{p}<0.001)$. From these 66 HPV DNA positive cases showing strong p16 ${ }^{\mathrm{INK} 4 \mathrm{~A}}$ staining 60 (90.9\%) were also HPV RNApositive. Six additional HPV DNA-positive cases showed no, weak, and moderate $\mathrm{p} 16^{\mathrm{INK} 4 \mathrm{~A}}$ immunohistochemistry signals in one, two, and three cases, respectively. For further information and distribution of mRNA positivity (only 2) among these cases refer to Table II. Of note, $32 / 98$ (32.7\%) specimens with strong $\mathrm{p} 16^{\mathrm{INK} 4 \mathrm{~A}}$ overexpression were HPV DNA and HPV mRNA-negative. Further HPV-negative cases $(n=235)$ showed 
Table III. Distribution of p16 $6^{\mathrm{INK} 4 \mathrm{~A}}$ staining pattern among the HPV-positive $(\mathrm{n}=72)$ and HPV-negative cases $(\mathrm{n}=235)$ discriminated by different health care centres for HNSCC cases overall and tonsillar cases in parenthesis.

\begin{tabular}{llccccc}
\hline & HPV-status & $\mathrm{p} 16^{\mathrm{INK} 4 \mathrm{~A}}-$ & $\mathrm{p} 16^{\mathrm{INK} 4 \mathrm{~A}}+$ & $\mathrm{p} 16^{\mathrm{INK} 4 \mathrm{~A}}++$ & $\mathrm{p} 16^{\mathrm{INK} 4 \mathrm{~A}}+++$ & Overall \\
\hline Rostock/Greifswald & Positive & $-/-$ & $-/-$ & $-/-$ & $22(20)$ & $22(43.1 \%)$ \\
& Negative & $5(3)$ & $5(3)$ & $14(7)$ & $5(3)$ & $29(56.9 \%)$ \\
Kiel/Lübeck & Positive & $1(1)$ & $2(0)$ & $-/-$ & $11(9)$ & $14(21.8 \%)$ \\
& Negative & $6(1)$ & $10(0)$ & $26(9)$ & $8(4)$ & $50(78.1 \%)$ \\
Oldenburg & Positive & $-/-$ & $-/-$ & $-/-$ & $12(12)$ & $12(21.8 \%)$ \\
& Negative & $4(1)$ & $10(1)$ & $20(7)$ & $9(5)$ & $43(78.2 \%)$ \\
Hanover & Positive & $-/-$ & $-/-$ & $1(1)$ & $11(10)$ & $12(28.6 \%)$ \\
& Negative & $8(3)$ & $7(3)$ & $9(1)$ & $6(4)$ & $30(71.4 \%)$ \\
Hamburg & Positive & $-/-$ & $-/-$ & $1(0)$ & $6(5)$ & $7(14 \%)$ \\
\multirow{3}{*}{ Cologne } & Negative & $8(1)$ & $9(2)$ & $23(9)$ & $3(1)$ & $43(86 \%)$ \\
& Positive & $-/-$ & $-/-$ & $1(0)$ & $4(1)$ & $5(11.1 \%)$ \\
Overall & Negative & $19(2)$ & $9(3)$ & $11(3)$ & $1(0)$ & $40(88.9 \%)$ \\
\hline
\end{tabular}

The cases negative for $\mathrm{p} 16^{\mathrm{INK} 4 \mathrm{~A}}$ and cases with weak or moderate $\mathrm{p} 16^{\mathrm{INK} 4 \mathrm{~A}}$ staining only exceptionally contain HPV infections. Cases with strong $\mathrm{p} 16^{\mathrm{INK} 4 \mathrm{~A}}$ staining, however, show in approximately two/thirds of cases investigated HPV infections (also see Table II), whereas, HPVpositive cases show with only few exceptions (for tonsillar SCC in only one exception) strong p16 ${ }^{\mathrm{INK} 4 \mathrm{~A}}$ staining.

no, weak, and moderate p16 $6^{\mathrm{INK} 4 \mathrm{~A}}$ expression in $50(21.3 \%), 49$ (20.9\%), and 104 (44.3\%) cases, respectively. In conclusion, for this specific study population in case of HPV DNA positivity only cases with strong diffuse immunohistochemical staining for $\mathrm{p} 16^{\mathrm{INK} 4 \mathrm{~A}}(+++)$ should be defined as $\mathrm{p} 16^{\mathrm{INK} 4 \mathrm{~A}}$-positive in terms of representing a surrogate marker for HPV activity (Fig. 2).

Presence of HPV DNA, E6/E7 mRNA expression and p16 $6^{I N K 4 A}$ expression, smoking habit and survival. Kaplan-Meier calculations demonstrated statistically significant better PFS and OS rates for HPV DNA ( $p=0.007$ and $p=0.014$, respectively) or HPV mRNA ( $\mathrm{p}=0.005$ and $\mathrm{p}=0.052$, respectively) positive cases (Fig. 3). Strong, moderate, weak and no p16 $6^{\mathrm{INK} 4 \mathrm{~A}}$ expression correlated with PFS ( $\mathrm{p}<0.001)$ with cases strongly expressing $\mathrm{p}^{\mathrm{INK} 4 \mathrm{~A}}$ showing the longest survival times (Fig. 3). Further Kaplan-Meier calculations showed better PFS rates for HPV DNA and p16 ${ }^{\text {INK4A }}$-positive cases in comparison to HPV DNA and $p 16^{\mathrm{INK} 4 \mathrm{~A}}$-negative cases $(\mathrm{p}=0.007$; HPV mRNA in combination with $\mathrm{p} 16^{\mathrm{INK} 4 \mathrm{~A}}$ expression, $\mathrm{p}=0.006$ ). For these parameters, the significance was lost when focussing on OS (Fig. 4). When analysing tonsillar and non-tonsillar SCC, out of 149 HPV DNA-negative non-tonsillar SCC cases 16 patients died within the observation time whereas all 11 patients with HPV DNA-positive non-tonsillar SCC are still alive. In comparison, out of 68 HPV DNA-negative tonsillar cases 9 patients died, whereas among the HPV DNA-positive cases of this group $1 / 48$ patients died ( $\mathrm{p}=0.03$ ). Survival data solely stratified for smoking habit showed a significant survival advantage for non-smoking patients $(\mathrm{p}<0.001)$. When stratifying the HPV-positive and HPV-negative patients combined with smoking habit in any combination survival data did not show differences in the course of diseases.
Fisher's exact test demonstrated strong correlations between HPV DNA and p16 ${ }^{\text {INK4A }}$, HPV DNA and E6/E7 mRNA expression, and between p16 ${ }^{\mathrm{INK} 4 \mathrm{~A}}$ and E6/E7 mRNA expression (each $\mathrm{p}<0.001)$.

\section{Discussion}

The results of this unique study retrospectively investigating 307 HNSCC patients with tonsillar and non-tonsillar SCC living in various regions of mostly Northern Germany reveals that i) besides a considerable proportion of tonsillar SCC there is a certain, albeit smaller subgroup, of patients with nontonsillar SCC which is HPV-driven, ii) there is a significant diversity of HPV prevalence rates obviously solely depending on geographical influences, iii) $\mathrm{p} 16^{\mathrm{INK} 4 \mathrm{~A}}$ alone seems to be a stronger predictor of survival than HPV alone or even in combination with $\mathrm{p} 16^{\mathrm{INK} 4 \mathrm{~A}}$ immunohistochemistry. In the following these intriguing results will be discussed in more detail.

With 23.5\% HPV DNA-positive cases overall and 44\% positive tonsillar cases the detected prevalence rates in the total study population were within the range expected for a German population. The by far lower HPV prevalence rate in this study population when compared to for instance Scandinavian study populations with HPV prevalence rates up to $90 \%(13,18)$ may be explained by the rather high proportion of smokers in our study population. It is well documented that in countries with successful anti-smoking campaigns the rise in incidence of HPV-related carcinomas is predominant. Focussing on the prevalence rates of the various cities in this study, the results show diversity in HPV prevalence of up to $60 \%$ (Table I).

Analysing FFPE tissue specimens, HPV DNA-positive cases could be detected in $44 \%$ of tonsillar SCC and in $8 \%$ of 

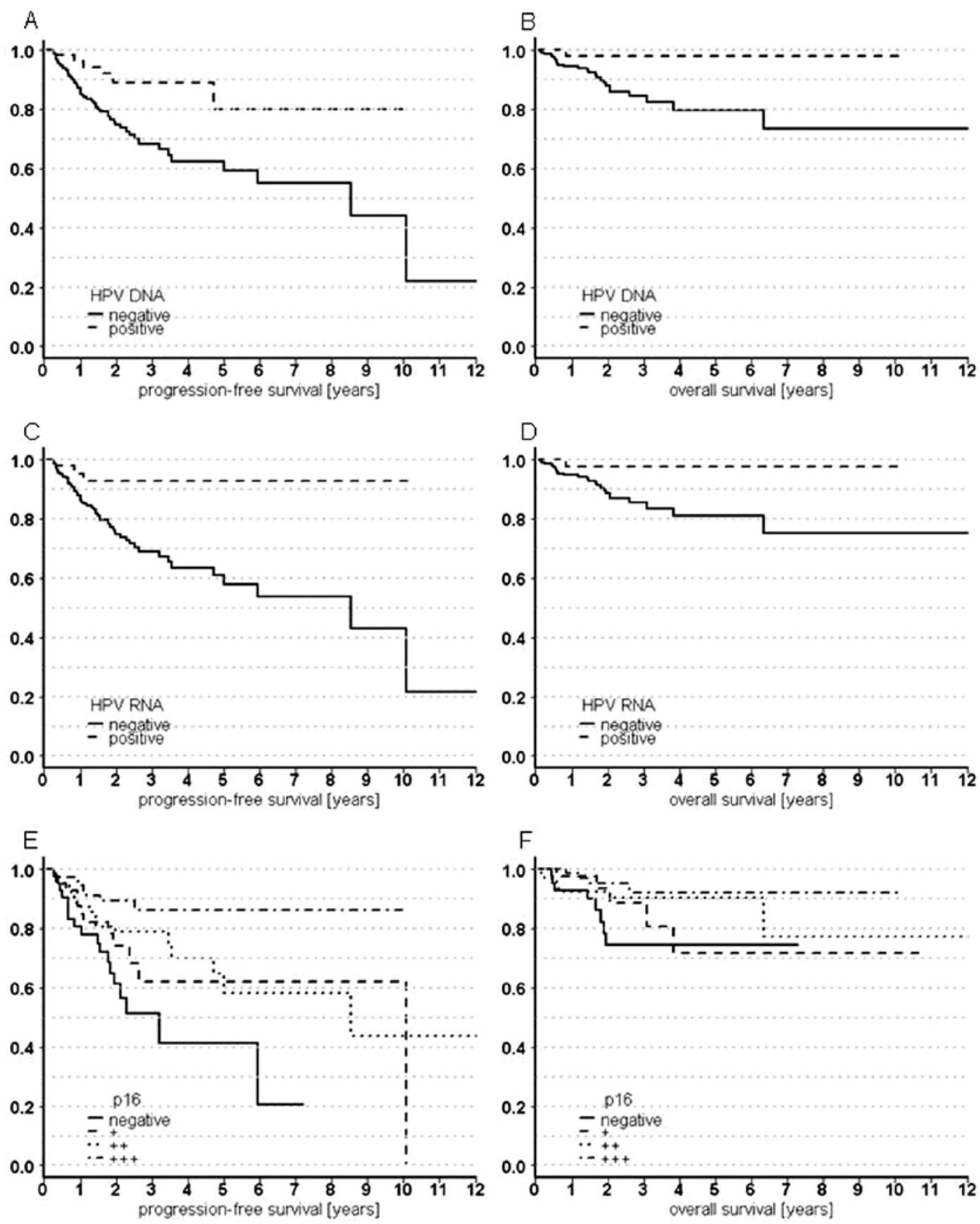

Figure 3. Kaplan-Meier curves showing progression-free survival (left panel) and overall survival (right panel), respectively, for HPV DNA (A and B), HPV mRNA $(C$ and $D), p 16^{\mathrm{INK} 4 \mathrm{~A}}(\mathrm{E}$ and $\mathrm{F})$. The data demonstrate that $\mathrm{p} 16^{\mathrm{INK} 4 \mathrm{~A}}$ alone is a better predictive factor for progression-free survival than all other parameters tested. Except for HPV DNA status all other parameters do not show significant differences for overall survival.

non-tonsillar cases (Table I). However, active HPV infections diagnosed by E6/E7 mRNA expression could only be detected in $38.5 \%$ of non-tonsillar SCC whereas $96.6 \%$ of tonsillar HPV DNA-positive SCC could be defined as HPV-driven. Hence, carcinogenic HPV infections in subsites outside the Waldeyers' tonsillar ring seem to be rather infrequent. These results are, thus, in agreement with other, specifically US-American HPV prevalence studies not regularly detecting HPV infections in SCC outside the oropharynx $(4,24,29,30)$. However, between 2005 and 2010, HPV DNA prevalence studies were performed in various study populations from Kiel (patients investigated overall, $n=314$ ) applying comparable detection methods as in the present study, yet, analysing fresh frozen tissue specimens $(8,9,15,31-34)$. The determined HPV prevalence rates in SCC from the Waldeyers' tonsillar ring, the oropharynx other than tonsils, oral cavity, larynx and hypopharynx were $56,13,28,24$ and $28 \%$, respectively. Moreover, in our recent study on the validity of $16^{\mathrm{INK} 4 \mathrm{~A}}$ immunohistochemistry for the identification of active HPV infections in HNSCC we showed that i) the vast majority of tonsillar SCC contains active HPV infections ii) whereas the approximate rate is $50 \%$ of SCC of non-tonsillar origin $(8,9)$. This diversity in HPV detection 

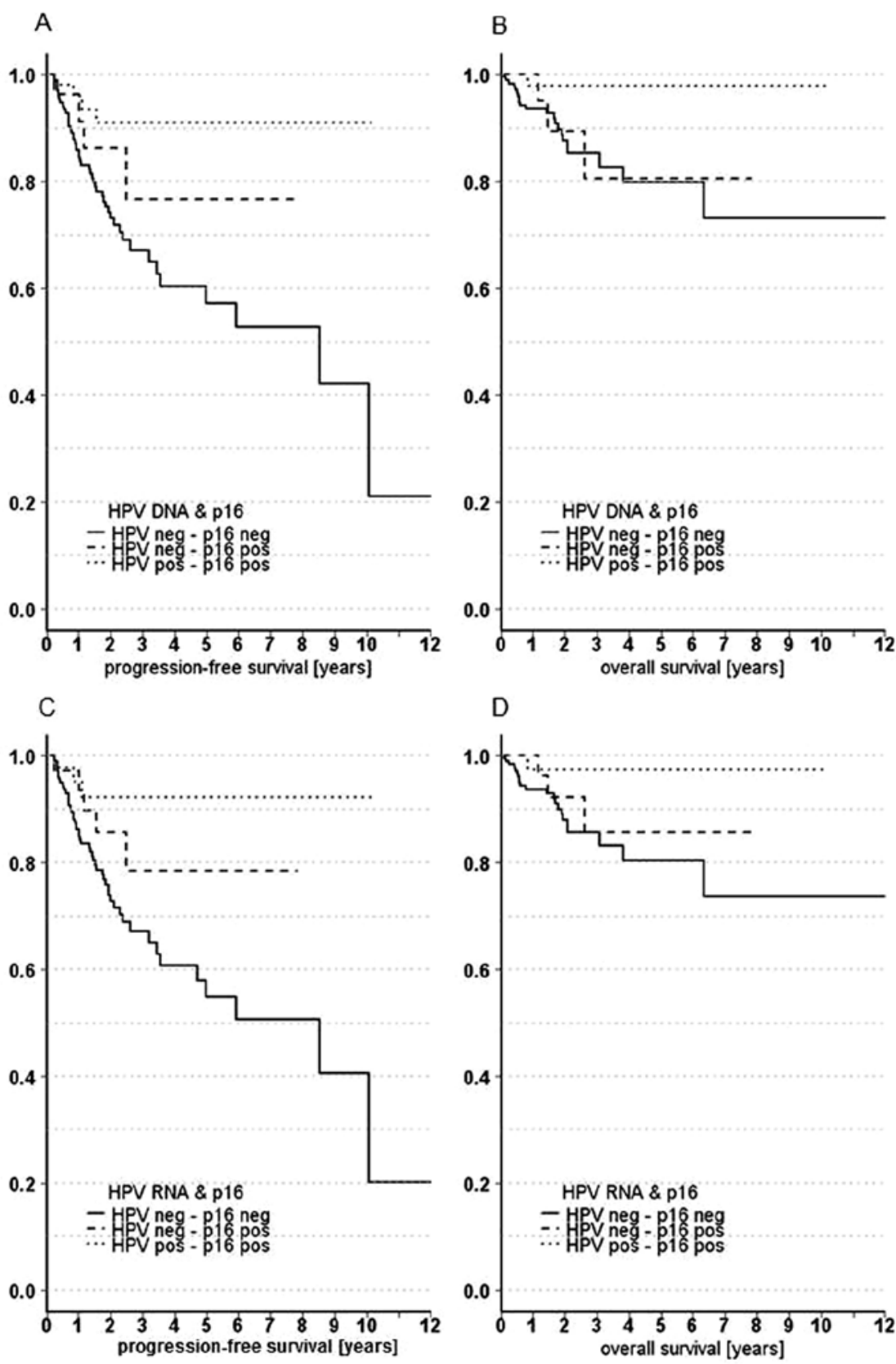

Figure 4. Kaplan-Meier curves showing progression-free survival (left panel) and overall survival (right panel), respectively, when analysing the combination of HPV DNA and p16 $6^{\text {INK4A }}(\mathrm{A} \text { and B })^{*}$, and HPV E6/E7 mRNA and p16 ${ }^{\text {INK4A }}\left(\mathrm{C}\right.$ and D)* ${ }^{*}$ The data show that HPV-negative cases, yet, positive for p16 ${ }^{\text {INK4A }}$ show survival rates between those of patients being positive for both, HPV and p16 ${ }^{\mathrm{INK} 4 \mathrm{~A}}$, and those patients negative for both parameters. "Due to the small number of cases, HPV positive but $16^{\text {INK4A }}$-negative cases were excluded from analysis.

rates in the former and the present study and specifically the fact that the population of non-tonsillar SCC patients from Kiel investigated in the present study does not show any HPV infections at all leads us to assume that these variations predominantly are caused by the different material used for HPV detection, namely FFPE vs. fresh frozen.

HPV prevalence obviously is also influenced by geographical aspects. Certainly, the knowledge on varying HPV prevalence rates when investigating populations from different continents or countries is well established $(4,13,16-19,35)$. However, here we demonstrate for the first time that these differences in prevalence rates with variations up to $60 \%$ do also exist in different regions of close proximity (for details see legend to Table I). We certainly assume that these variations are not caused by just the geographic region per se, but by variations in social aspects (smoking habit, alcohol consumption, education, income and so forth), and/or sexual behaviour triggered by the characteristics of the regions the patients live in. Due to the retrospective design of this study, parameters like alcohol consumption and sexual behaviour could not be evaluated reliably.

Survival analysis in the entire population demonstrated a statistical significant PFS and OS advantage for HPV DNA-positive cases (Fig. 3) with HPV DNA being the only parameter showing significant differences for OS. Although the survival benefit for HPV DNA-positive patients is very 
well documented again specifically for US-American populations $(1,5,6,14,36,37)$, this to our knowledge is only the second study on a German population showing this survival advantage when stratifying only for HPV DNA status (30). So far, we and others repeatedly could only find a statistical significant difference in PFS and OS in German study populations when combining HPV DNA status with parameters identifying biological active viruses, such as E6/E7 mRNA or p16 ${ }^{\text {INK4A }}$ expression $(7,8,15,22,24,37)$. A similar observation was reported for a US-American population, only recently (38). To explain these discrepancies, is rather challenging. Whether or not the analysed tissue material, FFPE vs. fresh frozen, has an impact on these differences remains speculative.

Noteworthy, $\mathrm{p} 16^{\mathrm{INK} 4 \mathrm{~A}}$ expression is a stronger predictor for PFS for all four expression levels [negative (-), weak $(+)$, moderate $(++)$, strong $(+++)$ ] discriminating different courses of disease than HPV DNA results. Interpretation of the $\mathrm{p} 16^{\mathrm{INK} 4 \mathrm{~A}}$ expression data seems interesting since our data clearly advocate to only interpret strong p16 $6^{\mathrm{INK} 4 \mathrm{~A}}(+++)$ staining as surrogate marker for active HPV infections (Fig. 2). Therefore, it remains unclear, why patients with moderate and weak $16^{\mathrm{INK} 4 \mathrm{~A}}$ signals also show differing survival curves, although these cases with only few exceptions are HPVnegative. In view of this fact, studies putatively analysing HPV-related survival results by measuring p16 ${ }^{\text {INK4A }}$ expression and correlating this with survival data without combining these data with other HPV-related parameters, such as HPV DNA or mRNA status, should be interpreted with caution. This wariness is supported by the presented data showing that HPV-negative cases, yet, positive for $16^{\mathrm{INK} 4 \mathrm{~A}}$ show survival rates between those of patients being positive for both, HPV and $\mathrm{p} 16^{\mathrm{INK} 4 \mathrm{~A}}$, and those patients negative for both parameters (Fig. 3). The reason for this needs to be further elucidated. However, it seems obvious that use of $\mathrm{p} 16^{\mathrm{INK} 4 \mathrm{~A}}$ immunohistochemistry alone does not reliably identify HPV-positive cases and should not be the basis of HPV-associated treatment studies as has repeatedly been the case in de-intensification studies for HNSCC patients (39-41).

Except for HPV DNA, all other parameters tested and showing significant correlations for PFS are lost when stratifying data for OS. This might be explained by co-morbidities of the patients in this population. Relevant co-morbidities can be assumed since the majority of patients are active smokers and, with a median age of 61 years, belong to a group where cardiovascular, perhaps smoking induced, morbidities occur rather regularly. Despite the fact that there is a significant correlation between HPV status and smoking habit with the group of non-smokers showing 44\% HPV-positive whereas the smokers do so in only $17 \%$, the proportion of smokers in the HPV-positive and HPV-negative groups is comparatively high. The latter might explain the loss of positive effects of HPV infection on patient survival rates when stratifying for HPV status in combination with smoking habit.

The presented data are an intense call for further nationwide prospective large scale investigations on HPV in HNSCC to clarify which factors contribute to the variations in HPV prevalence rates in different geographical regions such as sociodemographic aspects, such as smoking, alcohol consumption, education, income, sexual behaviour, martial status and others. In addition, there is a need for an intensive gain in knowledge and understanding of molecular mechanistic aspects discriminating HPV-infected, HPV-driven and HPV-independent cases. Furthermore, future studies ought to focus on mechanistic aspects concerning p $16^{\mathrm{INK} 4 \mathrm{~A}}$ involvement in head and neck carcinogenesis as single parameter and in the context of HPV infections. The molecular mechanisms producing better survival rates for HPV negative but $16^{\mathrm{INK} 4 \mathrm{~A}}$-positive patients need to be intensively investigated and, to this end, it must be clarified to what extent survival benefits observed for $\mathrm{p} 16^{\mathrm{INK} 4 \mathrm{~A}}$ positive patients can truly be attributed to HPV infections. In addition, these data clearly identify a subgroup of patients with HPV-driven HNSCC outside the oropharynx which should be considered for possible treatment shifts and cost-effectiveness calculations regarding HPV-vaccination.

\section{Acknowledgements}

The authors thank Sandra Krüger (Institute for Pathology) and Hilke Clasen (Institute of Immunology) for skilful technical assistance with immunohistochemistry and RNA-isolation, cDNA synthesis, (q)PCR, respectively, Dr Tomas Kahn for critically reading of the manuscript and continuous interest and Dr Gordana Halec (German Cancer Research Center, DKFZ, Heidelberg, Germany) who provided positive and negative controls for E6/E7-mRNA detection.

\section{References}

1. Fakhry C, Westra WH, Li S, et al: Improved survival of patients with human papillomavirus-positive head and neck squamous cell carcinoma in a prospective clinical trial. J Natl Cancer Inst 100: 261-269, 2008.

2. Gillison ML, Koch WM, Capone RB, et al: Evidence for a causal association between human papillomavirus and a subset of head and neck cancers. J Natl Cancer Inst 92: 709-720, 2000.

3. Klussmann JP, Weissenborn SJ, Wieland U, et al: Prevalence, distribution, and viral load of human papillomavirus 16 DNA in tonsillar carcinomas. Cancer 92: 2875-2884, 2001.

4. Kreimer AR, Clifford GM, Boyle P, et al: Human papillomavirus types in head and neck squamous cell carcinomas worldwide: a systematic review. Cancer Epidemiol Biomarkers Prev 14: 467-475, 2005.

5. Ang KK, J. Harris J, Wheeler R, et al: Human papillomavirus and survival of patients with oropharyngeal cancer. $\mathrm{N}$ Engl $\mathrm{J}$ Med 363: 24-35, 2010

6. Smith EM, Ritchie JM, Summersgill KF, et al: Age, sexual behavior and human papillomavirus infection in oral cavity and oropharyngeal cancers. Int J Cancer 108: 766-772, 2004.

7. Holzinger D, Schmitt M, Dyckhoff G, et al: Viral RNA patterns and high viral load reliably define oropharynx carcinomas with active HPV16 involvement. Cancer Res 72: 4993-5003, 2012.

8. Hoffmann M, Ihloff AS, Görögh T, et al: p16(INK4a) overexpression predicts translational active human papillomavirus infection in tonsillar cancer. Int J Cancer 127: 1595-1602, 2910.

9. Hoffmann M, Tribius S, Quabius ES, et al: HPV DNA, E6(*) I-mRNA expression and p16(INK4A) immunohistochemistry in head and neck cancer - How valid is p16(INK4A) as surrogate marker? Cancer Lett 323: 88-96, 2012.

10. Shi W, Kato H, Perez-Ordonez B, et al: Comparative prognostic value of HPV16 E6 mRNA compared with in situ hybridization for human oropharyngeal squamous carcinoma. J Clin Oncol 27: 6213-6221, 2009

11. Smeets SJ, Hesselink AT, Speel E-JM, et al: A novel algorithm for reliable detection of human papillomavirus in paraffin embedded head and neck cancer specimen. Int J Cancer 121: 2465-2472, 2007.

12. Wiest T, Schwarz E, Enders C, et al: Involvement of intact HPV16 E6/E7 gene expression in head and neck cancers with unaltered p53 status and perturbed pRb cell cycle control. Oncogene 21: $1510-1517,2002$. 
13. Attner P, Du J, Näsman A, et al: Human papillomavirus and survival in patients with base of tongue cancer. Int J Cancer 128: 2892-2897, 2011.

14. Tribius S, Ihloff AS, Rieckmann T, et al: Impact of HPV status on treatment of squamous cell cancer of the oropharynx: what we know and what we need to know. Cancer Lett 304: 71-79, 2011.

15. Hoffmann M, Görögh T, Gottschlich S, et al: Human papillomaviruses in head and neck cancer: 8 year-survival-analysis of 73 patients. Cancer Lett 218: 199-206, 2005

16. Straetmans JM, Olthof N, Mooren JJ, et al: Human papillomavirus reduces the prognostic value of nodal involvement in tonsillar squamous cell carcinomas. Laryngoscope 119: 1951-1957, 2009.

17. Hoffmann M, Kahn T, Mahnke CG, et al: Prevalence of human papillomavirus in squamous cell carcinoma of the head and neck determined by polymerase chain reaction and Southern blot hybridization: proposal for optimized diagnostic requirements. Acta Otolaryngol 118: 138-144, 1998.

18. Näsman A, Attner P, Hammarstedt L, et al: Incidence of human papillomavirus (HPV) positive tonsillar carcinoma in Stockholm, Sweden: an epidemic of viral-induced carcinoma? Int J Cancer 125: 362-366, 2009

19. Termine N, Panzarella V, Falaschini S, et al: HPV in oral squamous cell carcinoma vs. head and neck squamous cell carcinoma biopsies: a meta-analysis (1988-2007). Ann Oncol 19: 1681-1690, 2008

20. Pannone G, Rodolico V, Santoro A, et al: Evaluation of a combined triple method to detect causative HPV in oral and oropharyngeal squamous cell carcinomas: p16 immunohistochemistry, consensus PCR HPV-DNA, and in situ hybridization Infect Agent Cancer 7: 4, 2012, doi:10.1186/1750-9378-7-4.

21. Holzinger D, Flechtenmacher C, Henfling N, et al: Identification of oropharyngeal squamous cell carcinomas with active HPV16 involvement by immunohistochemical analysis of the retinoblastoma protein pathway. Int J Cancer 133: 1389-1400, 2013.

22. Kostareli E, Holzinger D, Bogatyrova O, et al: HPV-related methylation signature predicts survival in oropharyngeal squamous cell carcinomas. J Clin Invest 123: 2488-2501, 2013.

23. Reuschenbach M, Clad A, von Knebel Doeberitz C, et al: Performance of p16 ${ }^{\text {INK4a }}$-cytology, HPV mRNA, and HPV DNA testing to identify high grade cervical dysplasia in women with abnormal screening results. Gynecol Oncol 119: 98-105, 2010.

24. Reuschenbach M, Kansy K, Garbe K, et al: Lack of evidence of human papillomavirus-induced squamous cell carcinomas of the oral cavity in southern Germany. Oral Oncol 49: 937-942, 2013.

25. Remmerbach TW, Brinckmann UG, Hemprich A, et al: PCR detection of human papillomavirus of the mucosa: comparison between MY09/11 and $\mathrm{GP}^{+} / 6^{+}$primer sets. J Clin Virol 30 : 302-208, 2004.

26. Quabius ES, Ossenkop L, Harder S and Kern M: Dental implants stimulate expression of Interleukin-8 and its receptor in human blood - An in vitro approach. J Biomed Mater Res B Appl Biomater 100: 1283-1288, 2012.
27. Halec G, Schmitt M, Dondog B, et al: Biological activity of probable/possible high-risk human papillomavirus types in cervical cancer. Int J Cancer 132: 63-71, 2013.

28. Klaes R, Friedrich T, Spitkovsky D, et al: Overexpression of p16(INK4A) as a specific marker for dysplastic and neoplastic epithelial cells of the cervix uteri. Int J Cancer 92: 276-284, 2001

29. Gillison ML, D'Souza G, Westra W, et al: Distinct risk factor profiles for human papillomavirus type 16-positive and human papillomavirus type 16-negative head and neck cancers. J Natl Cancer Inst 100: 407-420, 2008.

30. Weiss D, Koopmann M and Rudack C: Prevalence and impact on clinicopathological characteristics of human papillomavirus-16 DNA in cervical lymph node metastases of head and neck squamous cell carcinoma. Head Neck 33: 856-862, 2011.

31. Hoffmann M, Gottschlich S, Görögh T, et al: Human papillomaviruses in lymph node neck metastases of head and neck cancers. Acta Otolaryngol 125: 415-4121, 2005.

32. Hoffmann M, Orlamünder A, Sucher J, et al: HPV16 DNA in histologically confirmed tumour-free neck lymph nodes of head and neck cancers. Anticancer Res 26: 663-670, 2006.

33. Hoffmann M, Klose N, Gottschlich S, Görögh T, Fazel A, Lohrey C, et al: Detection of human papillomavirus DNA in benign and malignant sinonasal neoplasms. Cancer Lett 239: 64-70, 2006.

34. Hoffmann M, Scheunemann D, Fazel A, et al: Human papillomavirus and p53 polymorphism in codon 72 in head and neck squamous cell carcinoma. Oncol Rep 21: 809-814, 2009.

35. Chaturvedi AK, Engels EA, Pfeiffer RM, et al: Human papillomavirus and rising oropharyngeal cancer incidence in the United States. J Clin Oncol 29: 4294-4301, 2011.

36. Chung CH and Gillison ML: Human papillomavirus in head and neck cancer: its role in pathogenesis and clinical implications. Clin Cancer Res 15: 6758-6762, 2009.

37. Klussmann JP, Mooren JJ, Lehnen M, et al: Genetic signatures of HPV-related and unrelated oropharyngeal carcinoma and their prognostic implications. Clin Cancer Res 15: 1779-1786, 2009.

38. Liang C, Marsit CJ, McClean MD, et al: Biomarkers of HPV in head and neck squamous cell carcinoma. Cancer Res 72: 5004-5013, 2012.

39. Lassen P, Eriksen JG, Hamilton-Dutoit S, et al: Effect of HPV-associated p16INK4A expression on response to radiotherapy and survival in squamous cell carcinoma of the head and neck. J Clin Oncol 27: 1992-1998, 2009.

40. Lassen P, Eriksen JG, Hamilton-Dutoit S, Tramm T, et al: HPV-associated p16-expression and response to hypoxic modification of radiotherapy in head and neck cancer. Radiother Oncol 94: 30-35, 2010.

41. O'Sullivan B, Hui Huang S, Siu LL et al: Deintensification candidate subgroups in human papillomavirus-related oropharyngeal cancer according to minimal risk of distant metastasis. J Clin Oncol 31: 543-550, 2013. 